\title{
Engaging Marina and Harbor Operators in Climate Adaptation
}

\author{
AMY SAMPLES ${ }^{1 *}$, CATHERINE RISENG ${ }^{1}$, JONATHON DAY ${ }^{2}$ \\ Volume 3, Spring 2015 \\ http://dx.doi.org/10.3998/mjs.12333712.0003.004 \\ 'Michigan Sea Grant, 520 E. Liberty St., Suite 310, Ann Arbor, MI 48104 \\ ${ }^{2}$ Purdue University, Marriott Hall, Room 255, 900 W. State Street, West Lafayette, IN \\ 47907 \\ "Corresponding author: Amy Samples, asamples@umich.edu
}

\section{ABSTRACT}

Great Lakes marinas and harbors experience a variety of climate change impacts including shorter winters, warmer temperatures, more intense storms, reduction in ice cover, and fluctuating lake levels. Though a variety of climate tools are available, private marinas and small municipal harbors are struggling to recognize and fund needed improvements that will increase climate resilience. A disconnect between private-sector industry (marinas), the public sector (municipal harbors and local decision-makers), and academia (climate researchers and research findings) results in a lack of confidence and coordination, which may deter responsive actions. This article describes the development and application of training resources to translate climate change research findings and assist marina and harbor operators in sectorspecific problem identification, decision-making and planning related to climate change adaptation. Information was conveyed using the Clean Marina program, an informal learning network, to streamline access to existing partnerships. In beta testing, a stakeholder-specific introduction to climate risks, impacts and resources was highly rated, which suggests the value of customizing climate information for sector-specific climate adaptation tools. Challenges of translating climate research findings for a specific audience included establishing access and trust, justifying adaptation as an immediate need, and accounting for potential bias against climate science. Customized climate resources, including identification of potential impacts 
alongside best practices for adaptation, framed scientific concepts in a way that resonated with the target audience and improved potential for action to increase climate resilience.

\section{Increasing Resilience at Marinas and Harbors}

Many Great Lakes coastal communities include small recreational harbors or private marinas that provide numerous social and economic benefits (Great Lakes Commission 2007) and a sense of place for the community. Marinas and harbors experience a variety of climate change impacts including shorter winters (Kling and Wuebbles 2005), warmer temperatures (U.S. Global Change Research Program 2009), more intense storms (Mortsch, Alden, and Scheraga 2003), reduction in ice cover (Wang et al. 2012), and fluctuating lake levels (Holman et al. 2012). Concurrently, marina infrastructure is aging and deteriorating, even as securing funding for needed improvements becomes increasingly difficult (USACE 2012).

A variety of climate adaptation tools are available but may be overwhelming to general audiences, including marina and harbor operators. A sense of information overload paired with uncertainty in environmental conditions may result in an overall lack of confidence in assessing or adopting potential responses. Such factors complicate - and sometimes deter - responsive actions in the face of environmental change and necessitate a structured approach to delivering information to stakeholders.

\section{Process}

Michigan Sea Grant led a team of industry, legal, science, education, and tourism professionals (Table 1) that developed training materials about climate change for marina and harbor operators. The "Increasing Resilience" training module was developed as a new unit of the Clean Marina Classroom (www.cleanmarinaclassroom. org), an online training tool for marina and harbor operators.

To refine existing understanding of stakeholder needs (Holladay 2013), the project team collected input on recognized environmental changes, associated impacts and preferred information sources from marina and harbor operators using a questionnaire available in person and online (Table 2). Operators reported lake-level changes and storm-related structural repairs as having the most impact on facilities, 
TABLE 1. Project team member affiliations and roles.

\begin{tabular}{ll}
\hline Member Affiliation & Project Role \\
\hline Michigan Sea Grant, Director & Lead Investigator \\
Michigan Sea Grant, Community Outreach Coordinator & Project Coordinator \\
Michigan Sea Grant, Clean Marina Program Educator & Extension Liaison, Marina Specialist \\
Michigan Sea Grant, Communications and Education & Communications Resources Manager \\
Services Director & \\
$\begin{array}{l}\text { Purdue University, Assistant Professor, Hospitality and } \\
\text { Tourism Management }\end{array}$ & Tourism and Marketing Specialist \\
NOAA GLERL, Physical Scientist & NOAA GLERL Resources Specialist, Great Lakes Water Level \\
& Dashboard Representative \\
$\begin{array}{l}\text { David L. Knight, LLC, CEO } \\
\text { National Sea Grant Law Center, Director; National } \\
\text { Working Waterfront Network, Co-chair }\end{array}$ & $\begin{array}{l}\text { Great Lakes Small Harbors Coalition Representative } \\
\text { Michigan Boating Industries Association, Former }\end{array}$ \\
$\begin{array}{l}\text { Chairman of Board of Directors; MacRay Harbor, } \\
\text { President and CEO }\end{array}$ & Marina Representative \\
$\begin{array}{l}\text { City of Petoskey, Marina Buildings and Groundskeeper; } \\
\text { Michigan Harbor Masters Association, Member }\end{array}$ & Michigan State Harbor Masters Association Representative \\
\hline
\end{tabular}

TABLE 2. Initial stakeholder questionnaire results for preferred tools and information sources $(n=13)$. Stakeholders responded to the following question: "Please let us know if you have heard of the following tools and if you use them to make management decisions at your marina or harbor."

\begin{tabular}{|c|c|c|c|c|c|c|}
\hline \multirow[t]{2}{*}{ Tool } & \multicolumn{4}{|c|}{ Response Categories } & \multirow[t]{2}{*}{$\begin{array}{c}\text { Total } \\
\text { Responses }\end{array}$} & \multirow[t]{2}{*}{ Mean } \\
\hline & $\begin{array}{l}\text { I have never } \\
\text { heard of this } \\
\text { tool. }\end{array}$ & $\begin{array}{c}\text { I have heard of } \\
\text { this tool, but } \\
\text { have never used } \\
\text { it. }\end{array}$ & $\begin{array}{l}\text { I have heard of } \\
\text { this tool and have } \\
\text { used it, but did } \\
\text { not find it useful. }\end{array}$ & $\begin{array}{l}\text { I have heard of this } \\
\text { tool and find it } \\
\text { useful when making } \\
\text { decisions about how } \\
\text { my marina / harbor } \\
\text { operates. }\end{array}$ & & \\
\hline $\begin{array}{l}\text { NOAA Great Lakes } \\
\text { Water Level Dashboard }\end{array}$ & 3 & 5 & 1 & 4 & 13 & 2.46 \\
\hline $\begin{array}{l}\text { NOAA Climate Adapted } \\
\text { Planning Resources }\end{array}$ & 6 & 5 & 0 & 2 & 13 & 1.85 \\
\hline $\begin{array}{l}\text { Monthly Bulletin of } \\
\text { Great Lakes Water Levels }\end{array}$ & 4 & 1 & 1 & 7 & 13 & 2.85 \\
\hline $\begin{array}{l}\text { Sustainable Working } \\
\text { Waterfronts Toolkit }\end{array}$ & 7 & 4 & 0 & 2 & 13 & 1.77 \\
\hline $\begin{array}{l}\text { Great Lakes Coastal } \\
\text { Resilience Planning } \\
\text { Guide }\end{array}$ & 7 & 4 & 0 & 1 & 12 & 1.58 \\
\hline $\begin{array}{l}\text { Word of mouth / advice } \\
\text { from shoreline neighbors } \\
\text { or industry peers }\end{array}$ & 3 & 3 & 1 & 6 & 13 & 2.77 \\
\hline $\begin{array}{l}\text { Other tool, practice, or } \\
\text { resource (please describe) }\end{array}$ & 0 & 0 & 0 & 1 & $1^{*}$ & 4.00 \\
\hline
\end{tabular}

Responses collected online and in-person from November 15, 2013 to January 30, 2014.

*Other entries: Tipp of the Mitt Watershed, Lake Charlevoix Association (entered and scored as one entry). 
and they expressed interest in grant funding assistance for adaptation projects and collaborative development of best practices. Training content was developed based on this input, existing adaptation guidance, advice from the project team, and feedback from workshops where operators provided insight on best practices.

Training content includes an overview of relevant environmental risks and potential impacts and a summary of topically organized resources and tools for marina and harbor operators in adapting to environmental variability and building resilience to climate change (Table 3). Each section features best practices and adapta-

TABLE 3. Summary of Increasing Resilience Unit training content.

\begin{tabular}{|c|c|}
\hline Section Title & Best Management Practices/Topic \\
\hline $\begin{array}{l}\text { Section 1: Potential Risks and } \\
\text { Impacts Background }\end{array}$ & $\begin{array}{l}\text { An overview of impacts and tools to educate users about the three major } \\
\text { environmental and climate-related changes most relevant to ports, harbors, and } \\
\text { marinas: } \\
\text { - Fluctuating water levels } \\
\text { - Increased storm frequency and intensity } \\
\text { - Precipitation and temperature changes }\end{array}$ \\
\hline Section 2: Infrastructure & $\begin{array}{l}\text { Best practices related to potential risks and adaptations for stormwater } \\
\text { management, buildings, wood infrastructure, floating docks, shoreline } \\
\text { protection, and pilings: } \\
\text { - Evaluate risks to infrastructure and grounds } \\
\text { - Invest in permanent adaptations }\end{array}$ \\
\hline Section 3: Dredging & $\begin{array}{l}\text { Best practices related to the complexity of jurisdictional considerations and } \\
\text { permit and funding requirements: } \\
\text { - Identify jurisdiction for dredging } \\
\text { - Collect required information } \\
\text { - Explore funding options }\end{array}$ \\
\hline Section 4: Planning and Financing & $\begin{array}{l}\text { Best practices for community adaptation planning, creating facility-specific } \\
\text { plans, and exploring financing options for applying adaptations: } \\
\text { - Represent your facility in community planning } \\
\text { - Create facility-specific plans } \\
\text { - Estimate costs of adaptation } \\
\text { - Explore financing options }\end{array}$ \\
\hline
\end{tabular}

tion approaches interpreted for marina and harbor operators. Companion print and web-based materials are publicly available and used by extension educators who work with shoreline businesses in relaying information on coastal resilience.

Beta testing review of the unit by representative facility operators and outreach specialists was positive (Table 4). Information from Section 1 was scored as "excellent" (easy to understand, applicable, and well presented), which suggests that the identification of sector-specific risks and related tools was valuable. This feedback indicates the potential value of customizing climate training information for other stakeholder groups. 
TABLE 4. Summary of beta testing results $(n=11)$.

\begin{tabular}{|c|c|c|c|c|c|c|}
\hline \multirow[t]{2}{*}{ Section Title } & \multicolumn{4}{|c|}{ Section Ratings* } & \multirow[t]{2}{*}{$\begin{array}{c}\text { Total } \\
\text { Responses** }\end{array}$} & \multirow[t]{2}{*}{ Mean } \\
\hline & $\begin{array}{c}\text { Needs } \\
\text { Not Useful Improvement }\end{array}$ & Adequate & Good & Excellent & & \\
\hline $\begin{array}{l}\text { Section } 1 \text { - Potential } \\
\text { Risks and Impacts } \\
\text { Background }\end{array}$ & 1 & & 4 & 6 & 11 & 4.4 \\
\hline $\begin{array}{l}\text { Section } 2 \text { - } \\
\text { Infrastructure }\end{array}$ & & & 5 & 6 & 11 & 4.5 \\
\hline Section 3 - Dredging & 1 & & 5 & 5 & 11 & 4.3 \\
\hline $\begin{array}{l}\text { Section } 4 \text { - Planning } \\
\text { and Financing }\end{array}$ & & & 4 & 7 & 11 & 4.6 \\
\hline
\end{tabular}

Beta testing conducted using Qualtrics survey instrument from October 22 to November 5, 2014.

*As defined in beta testing, "not useful" means the information was not relevant to marina or harbor operators, while "excellent" means it was easy to understand, applicable and well presented.

**Beta testing participants included representatives from the project team, Ohio Sea Grant, Wisconsin Sea Grant, Illinois Coastal Management Program, National Sea Grant Law Center, NOAA Great Lakes Environmental Laboratory, private and public marinas, and a private consulting practice.

\section{Overcoming Challenges}

We confronted several challenges that will inform the next generation of climate resilience tools.

\section{Establishing Access and Trust}

One challenge in customizing outreach efforts was establishing access and trust with stakeholders. We overcame this challenge by leveraging existing relationships with the Michigan Boating Industries Association, the Michigan State Harbor Masters Association, the Great Lakes Clean Marina Network, and the National Working Waterfront Network. The initial stakeholder questionnaire indicated that word of mouth and advice from industry peers were significant factors in how operators attain and apply information (Table 2). Leveraging connections with existing peer networks increased the efficacy of our outreach effort. Our results suggest that incorporating partners from peer networks was a key element in successful customized outreach. 


\section{Framing the Immediate Need}

A second challenge was focusing the attention of seasonal staff, an audience typically dedicated to day-to-day operations, on longer-term issues and solutions. One stakeholder group declined our invitation to formally collaborate, stating their need to focus on "immediate needs." Similarly, one beta tester noted a "challenge [in] overcoming preoccupation of marina owners (mostly small businesses and small communities) with more immediate concerns, like cash flow." Since marina and harbor patronage is vulnerable to impacts that influence infrastructure, aesthetics, and navigability, we framed these as operational risks. For example, we used images of marina damage from Hurricane Sandy to illustrate how increased storm intensity can impact a waterfront facility. For future efforts, we recommend framing climate adaptation as an immediate need to overcome temptations to delay or decline action.

\section{Overcoming Bias}

A third challenge was accounting for uncertainty about and personal bias against climate science. Our climate is changing - often in unpredictable ways - and it is difficult to convey the inherent uncertainties of climate science predictions. For example, extraordinarily low lake levels in 2013 attracted much public attention and sparked many demands for action, even though existing science predicts a wide range of lake-level changes (Lofgren, Hunter, and Wilbarger 2011; Holman et al. 2012), and lake levels rebounded in 2014. To curtail the potential roadblocks of climate change bias or mistrust of science, we provided current climate findings, related those predictions to risks faced by marina operators, explained the uncertainty of climate predictions, and focused our message on building resilience to a range of conditions.

\section{Conclusions}

Rapport with stakeholders - and thus the opportunity for effective education and outreach - was strengthened by the effort to frame scientific concepts in a way that resonates with the target audience. Leiserowitz and Maibach (2009) predicated their Six Americas research on the premises that "one of the first rules of effective communication is to "know thy audience" and that recognizing differences among 
people will result in more effective communication and engagement about climate change. We applied this concept by framing climate-related risks as threats to the facility or operations of harbors and marinas.

Findings from this research suggest that customized training materials were more accessible and useful if framed in a context and language familiar to the stakeholder, adapted to the priorities of the user (e.g., operational risks), and focused on building resilience to a range of conditions. If the training materials discuss impacts alongside potential adaptations, users are better prepared to recognize risks and identify and implement efforts to increase resilience to climate change (Hart and Feldman 2014).

\section{References}

Bidwell, David, Thomas Dietz, and Donald Scavia. 2013. "Fostering Knowledge Networks for Climate Adaptation.” Nature: Climate Change 3:610-611. Accessed July 25, 2013. doi:10.1038/ nclimate1931.

Great Lakes Commission. 2007. "Great Lakes Recreational Boating's Economic Punch.” Accessed July 25, 2013. http://www.glc.org/recboat/pdf/rec-boating-final-small.pdf.

Hart, P. Sol, and Lauren Feldman. 2014. "Threat without Efficacy? Climate Change on U.S. Network News." Science Communication 36 (3): 325-351. Accessed May 20, 2014. doi:10.1177/1075547013520239.

Holladay, Laura. 2013. "Climate Outreach Practices within Sea Grant Extension: A Needs Assessment Study for the Great Lakes Region.” Poster presented at the National Sea Grant Climate Network Workshop, Santa Monica, California, March 13, 2013.

Holman, Kathleen D., Andrew. D. Gronewold, Michael Notaro, and Azar Zarrin. 2012. "Improving Historical Precipitation Estimates over the Lake Superior Basin." Geophysical Research Letters 39:L03405. Accessed March 15, 2014. doi:10.1029/2011GL050468.

Kling, George, and Donald Wuebbles. 2005. "Confronting Climate Change in the Great Lakes Region: Impacts on Our Communities and Ecosystems. Executive Summary, Updated 2005.” Accessed July 25, 2013. http://www.ucsusa.org/greatlakes/glchallengereport.html.

Leiserowitz, A., and Edward Maibach. 2009. "Global Warming's Six Americas 2009: An Audience Segmentation Analysis.” Yale University and George Mason University. New Haven: Yale Project on Climate Change Communication. Accessed October 15, 2014. http://environment. yale.edu/climate-communication/files/SixAmericas2009.pdf.

Lofgren, Brent, Timothy Hunter, and Jessica Wilbarger. 2011. "Effects of Using Air Temperature as a Proxy for Potential Evapotranspiration on Climate Change Scenarios of Great Lakes Basin Hydrology." Journal of Great Lakes Research 37:744-752. Accessed June 20, 2014. doi:10.1016/j.jglr.2011.09.006.

Mortsch, Linda, Marianne Alden, and Joel D. Scheraga. 2003. "Climate Change and Water Quality in the Great Lakes Region: Risks, Opportunities, and Responses - A Report Prepared for the Great Lakes Water Quality Board of the International Joint Commission.” August. Accessed July 25, 2013. http://www.ijc.org/rel/pdf/climate_change_2003.pdf. 
USACE (U.S. Army Corps of Engineers). 2012. "Great Lakes Coastal Infrastructure: Critical Protection at Risk." Accessed August 7, 2014. http:/www.lre.usace.army.mil/Portals/69/docs/ Navigation/Risk\%20Com\%20-\%20GLCI-CPR_Brochure_\%20Jan_2012.pdf.

U.S. Global Change Research Program. 2009. "Global Climate Change Impacts in the United States: A State of Knowledge Report from the U.S. Global Change Research Program." Accessed July 25, 2013. http://library.globalchange.gov/products/assessments/2009-nationalclimate-assessment/2009-global-climate-change-impacts-in-the-united-states.

Wang, Jia, Xuezhi Bai, Haoguo Hu, Anne Clites, Marie Colton, and Brent Lofgren. 2012. “Temporal and Spatial Variability of Great Lakes Ice Cover, 1973-2010.” Journal of Climate 25:13181329. Accessed July 20, 2014. doi:10.1175/2011JCLI4066.1.

\section{Acknowledgments}

This project was funded by the Great Lakes Integrated Sciences and Assessments Center grant NA10OAR4310213. For more information on this project, see www. miseagrant.umich.edu/explore/boating-and-marinas/increasing-resilience-harborsmarinas. 